OmniAkuatika, 13 (1): 13-25, 2017
ISSN: 1858-3873 print / 2476-9347 online
Research Article

\title{
Observation of Wild Seaweed Species in Labuhanbua Waters, Indonesia: A Preliminary Assessment for Aquaculture Development
}

\author{
Erlania $^{\left.1^{*}\right)}$, ( Nyoman Radiarta ${ }^{2)}$ \\ ${ }^{\left.1^{*}\right)}$ Center for Fisheries Research, Ministry of Marine Affairs and Fisheries of Indonesia \\ Jl. Ragunan 20 Pasar Minggu, Jakarta Selatan 12540 \\ 2) Institute for Marine Research and Observation, Ministry of Marine Affairs and Fisheries of Indonesia \\ Jl. Baru Perancak, Negara-Jembrana, Bali 82251 \\ ${ }^{*}$ Corresponding author: erlania elleen@yahoo.com
}

Received 15 March 2017; Accepted 9 April 2017; Available online 25 May 2017

\begin{abstract}
Seaweed industry has been growing up and is supplied by either wild or cultivated seaweed crops. This study was aimed to investigated wild seaweed potency in Labuhanbua coastal waters, Sumbawa Regency, West Nusa Tenggara; and the potential use of important species as candidate for aquaculture commodities. 46 sampling stations were determined along line transects perpendicular to coastal line; and seaweed collections were conducted during low tide with $1 \times 1 \mathrm{~m}^{2}$ quadrat transect. Field data consist of in-situ parameter including number of seaweed species and coverage area of each species; and ex-situ parameters consist of carbohydrate, protein, total $\mathrm{C}$, total $\mathrm{N}$, and total $\mathrm{P}$ content of seaweeds. The results showed that 33 species were found and 3 species were dominant, i.e. Padina sp., Gracilaria Salicornia, and Dictyota dichotoma with the highest densities among other species, about $22.61 \%, 9.35 \%$, and $7.88 \%$, respectively. They also have potencies for human food, livestock feed, nutraceuticals, cosmetics, and any other industries. These might be important species that should be develop as aquaculture commodities candidates through culture technology advancement. Commercial scale cultivation of those important seaweed species will contribute to industrial needs and prevent decreasing wild seaweed availability in natural ecosystem.
\end{abstract}

Keywords: wild seaweed, aquaculture candidate species, Labuhanbua, West Nusa Tenggara

\section{Introduction}

Government of Indonesia through Ministry of Marine Affairs and Fisheries (MMAF) has determined that national fisheries production targets about 31 million tons for next five year during 2015-2019; which consist of seaweed production about 22 million tons. Indonesian coastal area has a great natural seaweed resources. Mostly, natural seaweed habitat in Indonesia can be found along coastal waters with reef flat; where its abundance and distribution depend on the substrate types, seasonal hydrography conditions, and species competition (Kadi 2004). They were found attached to the bottom, in relatively shallow coastal waters areas up to 180 meter depth, on solid substrates such as rocks, dead corals, pebbles, shells, and plants (Sahayaraj et al. 2014).

Labuhanbua coastal waters is one of locations which has abundant natural seaweed species which distributed along the reef flat at intertidal zone. Along that coastal area can be found various natural ecosystems including reef flat, mangrove, seagrass, and seaweed bed. Generally, people who live around the Labuhanbua coastal area still did not aware on economic values of the natural seaweeds. Sargassum sp. is the only species that has exploited by harvesting from its natural habitat. Other major species which have high value substances are still commonly unrecognized by local people.

Nowadays, seaweed industry has grown up; it uses 7.5-8.0 million tons of wet seaweed annually, either from naturally growing (wild) or from cultivated (farmed) crops (McHugh 2003). The farming of seaweed has expanded rapidly while demand has exceeded the supply available from natural resources (McHugh 2003). Although wild harvest supports a significant portion of seaweed industry, there is an ever-increasing amount of seaweed 
production from aquaculture, principally in Asia and South America (Redmond et al. 2014a). Seaweed aquaculture makes up a significant portion of organisms cultured worldwide $(\sim 19$ million metric tons) with a value of $\sim$ US $\$ 5.65$ billion (FAO 2012). About 25 million tons of seaweeds and other algae are harvested annually for use as food, cosmetics and fertilizers, and are processed to extract thickening agents or used as an additive to animal feed (FAO 2014).

Seaweed cultivation is a major industry in many countries of Asia-Pacific region, in particular Japan, Korea, and China (Hwang et al. 2007). Also in Indonesia, seaweed production volume from aquaculture contribute about $54,15-62,67 \%$ of national fisheries and aquaculture production during last five year (DGA-MMAF, 2014). Many seaweeds species have a great potency for food, feed, medicine, cosmetics and other industries, and mostly have been utilized at industrial level. But, there are limited number of seaweed species which have cultivated commercially in Indonesia, particularly some species from division of Rhodophyta such as Kappaphycus alvarezii, $K$. striatum, Eucheuma denticulatum, Gracilaria gigas, and G. verrucosa. On the other hand, the industries are still relying on seaweed supplies from natural resources; especially for certain species those are not yet cultivated.

Many efforts on seaweed research and development have been conducted to obtain cultivation technique of other potential seaweed species. Some species have been successfully cultivated, but large numbers of wild species are still not be able to cultivated well. Codium fragile, an edible green alga has been farmed in Korea using seed stock produced from artificial seed production and nursery culture
(Hwang et al. 2007). Undaria pinnatifida cultivation was largely developed in Korea for human consumption (Park et al. 2007). Gelidium has been cultured in Korea since 1989, but there is still no current commercial cultivation of this Gelidiales species (Friedlander 2007). There are still lack of study regarding the wild seaweed species around West Nusa Tenggara, specifically along Sumbawa coastal area.

Investigation on potential wild species for "new-aquaculture commodities" is now very important to be conducted, considering the wild seaweed ecosystem degradation caused by growing of industrial needs. While, industries need many kinds of substances from many seaweed species, yet the cultured species are still very limited. This study was aimed to investigate wild seaweed potency and the potential used of important species from Labuhanbua coastal waters, Sumbawa Regency, West Nusa Tenggara. It is expected that they can be developed as candidate species for next aquaculture commodities.

\section{Materials and Methods}

\section{Study Site}

The study was conducted at Labuhanbua coastal waters, Sumbawa Regency, West Nusa Tenggara Province, Indonesia (Figure 1a). This observation was conducted as a preliminary study to get initial information regarding wild seaweed varieties and their availability in Labuhanbua coastal ecosystem. Field data were collected on September 2014 with total wide area that have been observed about 173 ha. 

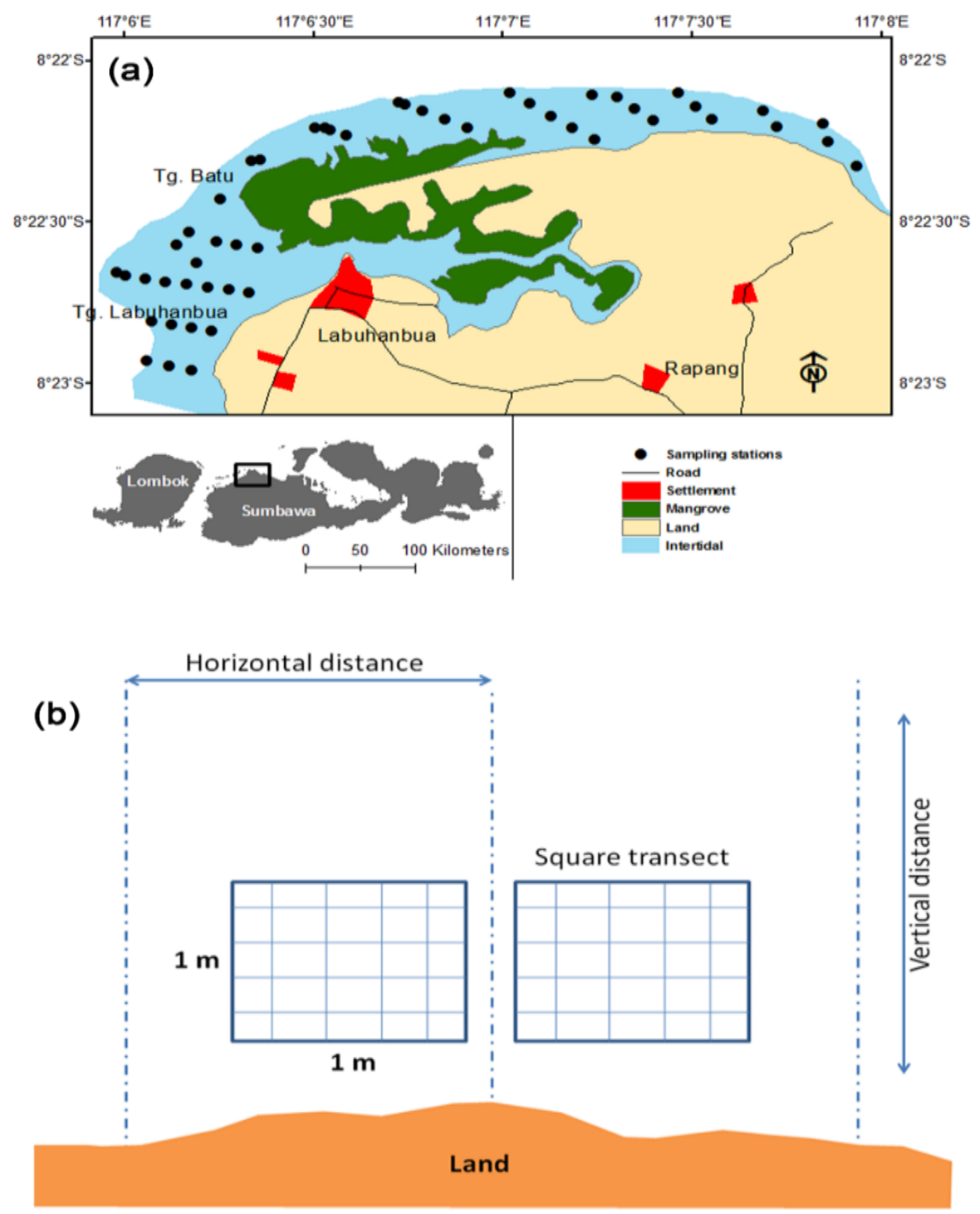

Figure 1. (a) Study location at Labuhanbua coastal waters, Sumbawa Regency, West Nusa Tenggara Province, and sampling stations distribution along the study location; (b) quadrat transects position on each sampling station

\section{Data collection}

Distribution of sampling stations was designed by Geographic Information System (GIS) using line transects perpendicular to coastal line along the intertidal area (Figure 1b). Distance between two neighboring line transect (horizontal distance) was about $250 \mathrm{~m}$. 46 sampling stations were determined along line transects which separated about $100 \mathrm{~m}$ of each other (vertical distance). Seaweed samplings were conducted during low tide with $1 \times 1 \mathrm{~m}^{2}$ quadrat transect that was subdivided into $20 \times 20 \mathrm{~cm}^{2}$ unit by string (Dawes, 1981; Dadolahi-Sohrab et al., 2012). Quadrat transects were placed at two sides of line transect at each sampling station for repetition data collection. Both of data obtained were calculated to get average value for each station. Data collection included number of seaweed species and percentage of coverage area of every single species at each quadrat transect for all of sampling stations. Seaweed species identification was based on Dhargalkar \& Kavlekar (2004) and Kalsum (2012).

Fifteen seaweed species were found in large quantities throughout the sampling stations, were collected by hand from their habitat and stored in plastic bags; then the seaweed samples were dried for laboratory analysis. Biochemical parameters were measured including total nitrogen (TN), total phosphorus (TP), total carbon (TC), carbohydrate, and protein contents of each species as percent dry weight (\% DW) with duplex-analysis methods for each parameter. $\mathrm{TN}$ and protein contents were measured using Kjeldahl method, while TP and TC using 
HNO3-HClO4 spectrophotometric and Walkey \& Black method, respectively (AOAC, 2005).

\section{Data analysis}

Collected data were analyzed using descriptive statistic methods and showed in tables and graphics. Field data obtained for each seaweed species were calculated following the formula below (Dawes, 1981; Dhargalkar \& Kavlekar, 2004) :

Frequency $=\frac{\text { number of occupied quadrats }}{\text { number of quadrats }}$

Abundance $(\%)=\frac{\text { total number of individual plants }}{\text { number of occupied quadrats }} \times 100$

Density $(\%)=\frac{\text { total number of individual plants }}{\text { total number of quadrats }} \times 100$

\section{Results and Discussion}

\section{Condition of sampling location}

Labuhanbua coastal water has great varieties of wild seaweed along the intertidal area. Seaweed species were distributed from coastline toward the reef edge area where the water depth about $0-3$ meters. Sea-bottom substrates were composed by sand, mud, pebbles, and coral stone. Measurement of some important water quality parameters described the characteristics of Labuhanbua water area where various seaweed species spread and grow. The range of salinity measured were about $34-37$ ppt; turbidity from $0.30-9.00 \mathrm{NTU}$; total N $0.16-0.95 \mathrm{mg} / \mathrm{L}$; and total $\mathrm{P}$ about $0.01-1.15 \mathrm{mg} / \mathrm{L}$. Nitrogen and phosphorus are primary elements for plant growth (Dawes, 1981).

\section{Ecological assessment of wild seaweed}

Labuhanbua coastal waters which located at Sumbawa Regency, West Nusa
Tenggara Province has fairly large diversity of natural seaweed ecosystem. Thirty three species were collected from 46 sampling stations along the coastal waters of Labuhanbua which consist of three divisions of natural seaweeds, namely Rhodophyta (8 species), Phaeophyta (8 species), and Chlorophyta (13 species); and also four species were found as unidentified species. Distribution of seaweed species is shown in Figure 2. A species from division of Phaeophyta, Padina $\mathrm{sp}$., was the most widely distributed which was found at 28 stations out of 46 total number of sampling stations (Figure 2). The result of ecological quantitative analysis on each seaweed species also showed that Padina sp. had the highest frequency $(0.61)$ which mean that the species was found at $61 \%$ of the total sampling stations (Table 1). Dictyota dichotoma, species of Phaeophyta was the second widely distributed which was found at 14 sampling stations. Gracilaria salicornia from division of Rhodophyta followed as the third widely distributed species, that was found at 11 stations. Several species of Chlorophyta and some unidentified species were only distributed at limited stations which ranged from $1-8$ stations along that coastal waters with frequencies range about $0.02-0.17$ (Table 1, Figure 2). A regular distribution of species and communities is particularly obvious on rocky shore, as has long been recognized by marine biologist (Neto, 2000). Fleshy brown macroalgae, including Padina and Dictyota are abundantly found on shallow inshore reef flat (Diaz-Pulido \& McCook, 2008). Seaweeds species will be distributed differently on natural ecosystem depend on their types and adaptation capability on the environmental conditions. Seaweed growth and distribution are affected by environmental factors such as salinity and light; as well as substrate characteristics may also be important factor to influence the distribution of seaweed types (Dawes, 1981; Tyler, 2010). 


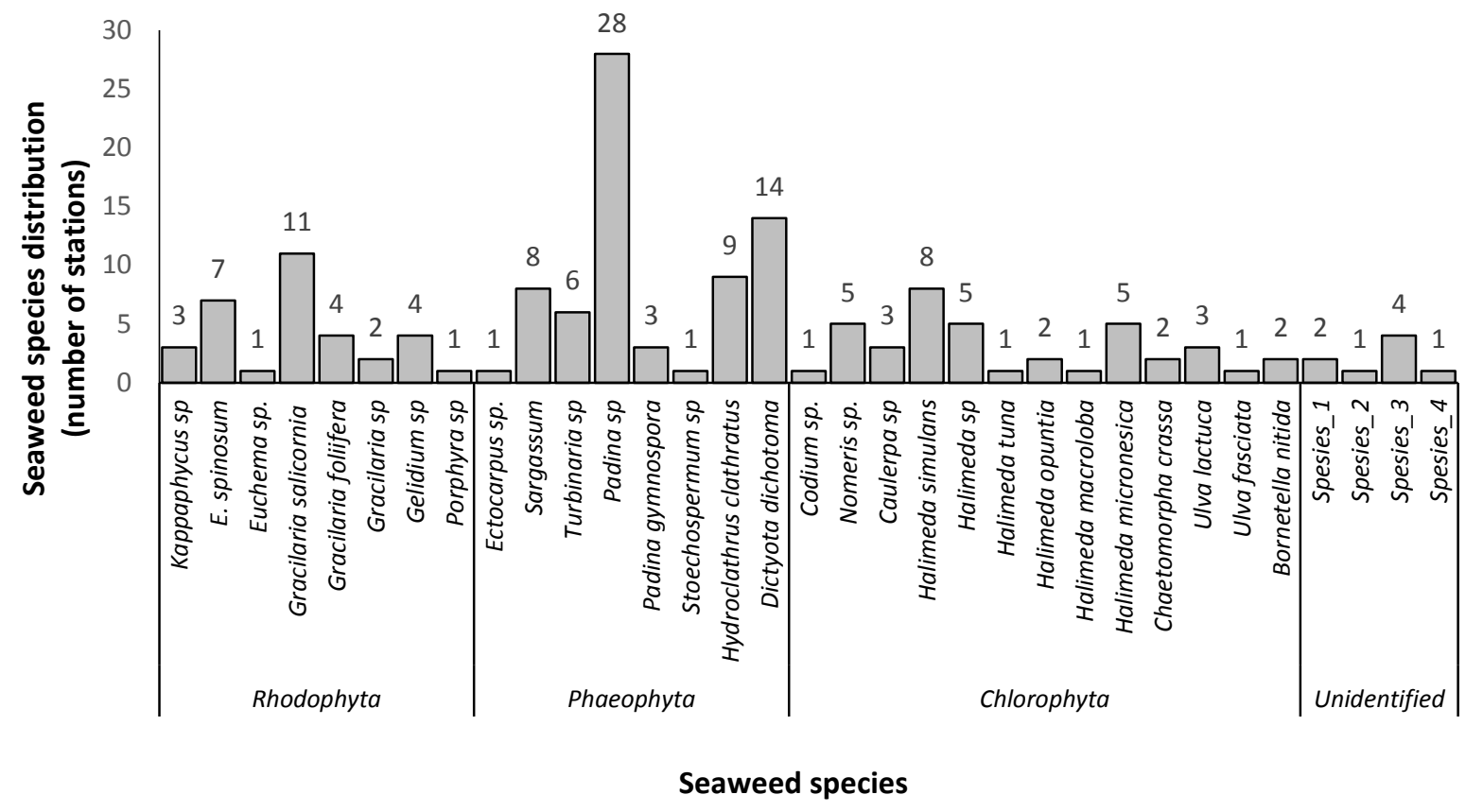

Figure 2. Seaweed species distribution of total 46 observation stations at Labuhanbua coastal waters, Sumbawa Regency, West Nusa Tenggara Province

Seaweed species abundance describes average number of a species on several stations where that species was found. Eucheuma sp. was found as the highest abundance species of Rhodophyta division at Labuhanbua coastal water. This species had average abundance about $50 \%$ of the occupied quadrats; but its density only $1.09 \%$ of the total sampling station observed (Table 1). Ectocarpus sp. was the highest abundance species of Phaeophyta; its abundance attained $100 \%$ (Table 1). Based on field observation, this species was only found at one station and occupied spread all over the quadrats; thereby its density only $2.17 \%$ of the total observation area (Table 1). Some species of Chlorophyta were found with high abundance. Those species were including Ulva fasciata, Chaetomorpha crassa, U. lactuca, and Codium sp. with their abundance about $60.00 \%, 56.25$ $\%$, $50.83 \%$, and $50.00 \%$, respectively. However, their densities were not the highest among other species at the same division which ranged about $1.09-3.32 \%$. Two Chlorophyta species were found in highest density including Halimeda sp. and $\mathrm{H}$. simulans with densities of $7.61 \%$ and $7.28 \%$, respectively (Table 1). In addition, four unidentified species were also found at study location which had abundance range about $25.00-84.75 \%$ and densities of $0.54-7,37 \%$ (Table 1). In context of the sustainability of seaweed fishery, the exploitation has to consider its distribution and abundance before authorizing the harvesting of natural populations (Vásquez, 2007). 
Table 1. Ecological quantitative assessment of seaweed species at Labuhanbua coastal waters, Sumbawa Regency, West Nusa Tenggara Province

\begin{tabular}{|c|c|c|c|c|}
\hline No. & Seaweed species & Frequency & Abundance (\%) & Density (\%) \\
\hline & Rhodophyta & & & \\
\hline 1 & Kappaphycus sp. & 0.07 & 15.83 & 1.03 \\
\hline 2 & Eucheuma spinosum & 0.15 & 23.57 & 3.59 \\
\hline 3 & Eucheuma sp. & 0.02 & 50.00 & 1.09 \\
\hline 4 & Gracilaria salicornia & 0.24 & 39.09 & 9.35 \\
\hline 5 & Gracilaria foliifera & 0.09 & 33.13 & 2.88 \\
\hline 6 & Gracilaria sp. & 0.04 & 10.00 & 0.43 \\
\hline 7 & Gelidium sp. & 0.09 & 16.88 & 1.47 \\
\hline \multirow[t]{2}{*}{8} & Porphyra sp. & 0.02 & 6.00 & 0.13 \\
\hline & Phaeophyta & & & \\
\hline 9 & Ectocarpus sp. & 0.02 & 100.00 & 2.17 \\
\hline 10 & Sargassum sp. & 0.17 & 31.25 & 5.43 \\
\hline 11 & Turbinaria sp. & 0.13 & 16.67 & 2.17 \\
\hline 12 & Padina sp. & 0.61 & 37.14 & 22.61 \\
\hline 13 & Padina gymnospora & 0.07 & 26.67 & 1.74 \\
\hline 14 & Stoechospermum sp. & 0.02 & 25.00 & 0.54 \\
\hline 15 & Hydroclathrus clathratus & 0.20 & 33.89 & 6.63 \\
\hline \multirow[t]{2}{*}{16} & Dictyota dichotoma & 0.30 & 25.89 & 7.88 \\
\hline & Chlorophyta & & & \\
\hline 17 & Codium sp. & 0.02 & 50.00 & 1.09 \\
\hline 18 & Nomeris sp. & 0.11 & 28.50 & 3.10 \\
\hline 19 & Caulerpa sp. & 0.07 & 38.33 & 2.50 \\
\hline 20 & Halimeda simulans & 0.17 & 41.88 & 7.28 \\
\hline 21 & Halimeda sp. & 0.11 & 70.00 & 7.61 \\
\hline 22 & Halimeda tuna & 0.02 & 10.00 & 0.22 \\
\hline 23 & Halimeda opuntia & 0.04 & 23.75 & 1.03 \\
\hline 24 & Halimeda macroloba & 0.02 & 22.50 & 0.49 \\
\hline 25 & Halimeda micronesica & 0.11 & 48.00 & 5.22 \\
\hline 26 & Chaetomorpha crassa & 0.04 & 56.25 & 2.45 \\
\hline 27 & Ulva lactuca & 0.07 & 50.83 & 3.32 \\
\hline 28 & Ulva fasciata & 0.02 & 60.00 & 1.30 \\
\hline \multirow[t]{2}{*}{29} & Bornetella nitida & 0.04 & 11.25 & 0.49 \\
\hline & Unidentified & & & \\
\hline 30 & Spesies_1 & 0.04 & 35.00 & 1.52 \\
\hline 31 & Spesies_2 & 0.02 & 30.00 & 0.65 \\
\hline 32 & Spesies_3 & 0.09 & 84.75 & 7.37 \\
\hline 33 & Spesies_4 & 0.02 & 25.00 & 0.54 \\
\hline
\end{tabular}

Biochemical contents of dominant seaweed species

Several numbers of macrophytes species have been a part of human food source (Sharp et al., 2007, Hwang et al., 2007). A large resources of wild seaweed is available at Labuhanbua coastal waters. These also have great potencies for further management and possible development related to market demand including several needs for human food, animal feed, biofuel, cosmetics, pharmaceutical, and carbon sink agent (McHugh, 2003; Erlania \& Radiarta, 2014). Seaweeds found to be good sources of proteins, carbohydrates, vitamins, and minerals in human nutrition; marine algae contain various carbohydrates different from those in higher land plants, and in addition, high protein content has been reported (Chakraborty \& Santra, 2008; Manivannan, 2008; Pise \& Sabale, 2010). Three broad group of seaweed 
classified based on pigmentation also show their potencies to produce valuable pigment substances including chlorophylls-a, b, c, and $\mathrm{d}$; phycoerythrin, phycocyanin, $\alpha$-carotene, $\beta$ carotene, lutein, fucoxanthin, etc. (Dawes, 1981; Naguit \& Tisera, 2009; Thirumaran, 2009).

Fifteen dominant species were found at Labuhanbua waters. Some primary biochemical contents have been analyzed including parameters of carbohydrate, protein, total $\mathrm{N}$, total $P$, and total $C$ contents (Table 2). Several species of seaweed accumulate high level of carbohydrate. Total carbohydrate content varied from $1.15-19.09 \%$ biomass. There were three species, Caulerpa sp., Gracilaria salicornia and Halimeda sp., contain the highest number of carbohydrate in their tissues among other species that ranged about 15.89 $19.09 \%$ (Table 2). Production of carbohydrate rich plant biomass is needed; biofuels such as bioethanol or butanol derived from carbohydrates fermentation of plant biomass (Kraan, 2013). Macroalgal polysaccharides (polymer of carbohydrate) are used in the food, cosmetics, paint, crop, textile, paper, rubber and building industries (Dere et al., 2003). Main polysaccharide extracts from seaweed, called phycocolloids/hydrocolllids, that are not found in terrestrial plants, includes carrageenan, agar, and algin which account for about $95 \%$ of the commercially available seaweed extracts; and the rest consist of furcellarin, funoran, and porphyran (Dawes, 1981; Carlsson et al., 2007). Total protein content of several dominant seaweed at Labuhanbua coastal waters were vary in different species and ranged from $3.25-12.63 \% \mathrm{DW}$ (Table 2). The highest protein contents were found in Caulerpa sp. (12.63 \%) and Gracilaria sp. (10.75\%). Chakraborty \& Santra (2008) found that protein content of eight seaweed species at Sunderban coastal waters, India showed significant individual variation from $3.33 \%$ (Dictyota ceylanica) to $40.87 \%$ (Lola capillaris) of dry weight.

Nitrogen, phosphorus, and carbon are very important elements for seaweed growth. Seaweed tissue carbon would be present in species variability (Muraoka, 2004; Kaladharan, 2009; Erlania \& Radiarta, 2014a). Seaweed capture carbon as $\mathrm{CO}_{2}$ during photosynthesis process and convert it into carbohydrate for biomass production (Dawes, 1981; Erlania \& Radiarta, 2014b). This macroalgae can represent major progress in several senses including: higher carbohydrate levels and biomass yields, their widespread availability, the absence of a competition with agricultural area, the high quality of the by-products, their use as a mean to capture $\mathrm{CO}_{2}$, and their suitability for integrating in wastewater treatments to reduce pollution (Kraan, 2013).

Table 2. Carbohydrate, protein, TC, TN, and TP content (\% DW) of dominant seaweed species found at Labuhanbua coastal waters, Sumbawa Regency, West Nusa Tenggara Province

\begin{tabular}{clccccc}
\hline No. & Seaweed species & Carbohydrate & Protein & TC & TN & TP \\
\hline 1 & Caulerpa sp. & $\mathbf{1 9 . 0 9}$ & $\mathbf{1 2 . 6 3}$ & $\mathbf{2 5 . 6 6}$ & $\mathbf{2 . 0 2}$ & $\mathbf{0 . 1 0 3}$ \\
2 & Gracilaria salicornia & $\mathbf{1 7 . 5 5}$ & 5.38 & $\mathbf{2 3 . 0 0}$ & 0.86 & 0.074 \\
3 & Halimeda sp. & $\mathbf{1 5 . 8 9}$ & 7.00 & 9.82 & 1.12 & 0.080 \\
4 & Ulva reticulata & 9.46 & 5.94 & 20.37 & 0.95 & $\mathbf{0 . 1 0 7}$ \\
5 & Gracilaria sp. & 9.41 & $\mathbf{1 0 . 7 5}$ & 19.59 & $\mathbf{1 . 7 2}$ & 0.082 \\
6 & Eucheuma spinosum & 9.18 & 7.19 & 16.47 & 1.15 & 0.058 \\
7 & Turbinaria sp. & 7.82 & 5.81 & $\mathbf{2 2 . 0 4}$ & 0.93 & 0.056 \\
8 & Gelidium sp. & 7.72 & 7.56 & 16.41 & $\mathbf{1 . 2 1}$ & 0.066 \\
9 & Bornetella nitida & 6.32 & 5.38 & 9.07 & 0.86 & 0.037 \\
10 & Dictyota dichotoma & 6.07 & 7.56 & 18.69 & $\mathbf{1 . 2 1}$ & $\mathbf{0 . 0 9 1}$ \\
11 & Sargassum sp. & 4.17 & 5.94 & 16.41 & 0.95 & 0.073 \\
12 & Padina sp. & 4.10 & 8.88 & 14.18 & $\mathbf{1 . 4 2}$ & 0.079 \\
13 & Halimeda micronesica & 1.66 & 3.25 & 4.53 & 0.52 & 0.041 \\
14 & Hydroclathrus clatratus & 1.15 & 8.63 & 11.78 & $\mathbf{1 . 3 8}$ & 0.086 \\
\hline
\end{tabular}


Seaweeds also absorb nutrient from seawater including $\mathrm{N}$ and $\mathrm{P}$ for their growth. $\mathrm{N}$ and $P$ contents of wild seaweed species were found in individual variation. Variability of seaweed tissue $\mathrm{N}$ and $\mathrm{P}$ can also be explained by coastal oceanographic process; $\mathrm{N}$ and $\mathrm{P}$ contents in the seaweeds correspond with a seasonal increase in $\mathrm{N}$ and $\mathrm{P}$ concentrations in the seawater (Robertson-Andersson et al., 2007). Fifteen analyzed seaweed species have $\mathrm{N}$ content ranged about $0,52-2,02 \%$; $\mathrm{P}$ about $0,041-0,107 \%$; and $\mathrm{C}$ about $4,53-25,66 \%$ (Table 2). Concerned with nutrients, the surface ocean contains almost $2 \times 10^{15}$ metric tonnes of nitrogen in a usable form by seaweed (Kraan, 2013). The potential nitrogen removal may be larger by developing seaweed farming area. Nitrogen is one of important elements to form pigment structure of seaweed including chlorophylls, phycobilins, carotenoids; photosynthetic pigments in seaweed (Dawes, 1981), thus variation of $N$ and $C$ contents in seaweed species are related to variation of pigments level. Chakraborty \& Santra (2008) showed that the quantity of carbohydrate and chlorophyll-a contents in benthic macroalgae displayed significant individual differences, respectively, ranged about $14,34-35,27 \%$ of dry weight and $0,37-2,45 \mathrm{mg} / \mathrm{g}$.

Development opportunity of important seaweed species in aquaculture

Algal biomass can be used for sustainable production of bioethanol and a great variety of other pruducts, including plastics, protein, and other valuable chemicals such as pigments (Kraan, 2013). Amongst about 33 seaweed species found in Labuhanbua coastal waters, some species have been widely utilized in various purpose, including Kappaphycus sp., Eucheuma sp., Gracilaria sp., Caulerpa sp., Gelidium sp., Sargassum sp., Codium sp., and Ulva sp.; and the rest are not yet commercially utilized (Tabel 3). Gelidium sp. is such an excellent source of high quality agar (McHugh, 2003). Gelidium sp. also has been used in papermaking; where pulp of high brightness can be produced by extracting mucilaginous carbohydrates of this red algae; and the by-products from processing have been converted into bioethanol; Ulva has high level of polysaccharide, a carbohydrate compound, that has been used in ethanol and methane production (Kraan, 2013; Seo et al., 2010). Shibu \& Dhanam (2013) reported that five marine algae species (Caulerpa recemosa, Turbinaria conoides, Halimeda micronesica, Padina gymnospora, and Sargassum polycystum) showed their antibacterial activities at different concentrations against the following bacteria Staphylococcus aureus, Bacillus cereus, Micrococcus luteus, Escherichia coli, Aeromonas hytrophila. Porphyra known commonly as nori in Japan, zicai in China, and purple laver in Great Britain) is a source of seafood for humans (Varela-Álvarez, 2007).

Increasing of market demand on seaweed for industrial uses will cause over exploitation and decreasing of seaweed natural stock. Restoration of the original ecosystem conditions will need a long-term process, while the seaweed industry lacked for continuous raw material supply. Important seaweed species need to be produced artificially by growing-out them using cultivation technology. Seaweed grow-out technology can be made in several methods. They can be grown with a simple system vegetatively in open waters on the bottom bays, estuaries or reef flat; on lines, ropes or nets; in ponds; or in tanks (McHugh, 2003). Every seaweed culture system requires a few main ingredients for successful culture; the three most important components of a culture system are seawater media (seawater and nutrients), temperature and light; seaweed must be placed at some depth below the surface of the water that will provide sufficient amount of sunlight (Redmond et al, 2014a). 
Table 3. Utilization and potential uses of wild seaweed species

\begin{tabular}{|c|c|c|c|c|c|c|}
\hline Seaweed species & $\begin{array}{l}\text { Human } \\
\text { Food }\end{array}$ & $\begin{array}{l}\text { Livestock } \\
\text { Feed }\end{array}$ & Nutraceutical & Cosmetic & Other purposes & Remarks \\
\hline \multicolumn{7}{|l|}{ Rhodophyta } \\
\hline $\begin{array}{l}\text { Kappaphycus sp. } \\
\text { (cottonii) }\end{array}$ & + & + & + & + & toothpaste industry & cultivated \\
\hline $\begin{array}{l}\text { Eucheuma spinosum } \\
\text { (cottonii) }\end{array}$ & + & + & + & + & toothpaste & cultivated \\
\hline Eucheuma sp. (cottonii) & + & + & + & + & toothpaste & cultivated \\
\hline Gracilaria salicornia & + & + & + & + & agarose & cultivated \\
\hline Gracilaria foliifera & + & + & + & + & agarose & cultivated \\
\hline Gracilaria sp. & + & + & + & + & agarose, iodine, vit. C & cultivated \\
\hline Gelidium sp. & + & + & - & - & pulp industry, bioethanol & cultivated \\
\hline Porphyra sp. (nori) & + & - & - & - & & cultivated \\
\hline \multicolumn{7}{|l|}{ Phaeophyta } \\
\hline Ectocarpus sp. & - & - & - & - & & natural \\
\hline Dictyota dichotoma & + & + & + & - & fucoidan & natural \\
\hline Padina sp. & + & + & + & - & fucoidan & natural \\
\hline Padina gymnospora & - & - & - & - & & natural \\
\hline Stoechospermum sp. & - & - & + & - & & natural \\
\hline Hydroclathrus clathratus & - & - & + & - & fucoidan & natural \\
\hline Turbinaria sp. & + & - & $\begin{array}{l}+ \\
+\end{array}$ & + & pulp \& textile industry, fucoidan, polyphenol, fucosterol & natural \\
\hline Sargassum sp. & + & + & + & + & algin, tanin, phenol, iodine, vit. C, biofuel, manure, pulp, textile & cultivated \\
\hline \multicolumn{7}{|l|}{ Chlorophyta } \\
\hline Codium sp. & + & - & + & - & & cultivated \\
\hline Nomeris sp. & - & - & - & - & & natural \\
\hline Caulerpa sp. & + & - & + & + & vit. C, mineral & cultivated \\
\hline Halimeda simulans & - & - & - & - & source of carbonate & natural \\
\hline Halimeda sp. & - & - & + & - & source of carbonate & natural \\
\hline Halimeda tuna & - & - & - & - & source of carbonate & natural \\
\hline Halimeda opuntia & - & - & - & - & source of carbonate & natural \\
\hline Halimeda macroloba & - & - & + & - & source of carbonate, growth factor & natural \\
\hline Halimeda micronesica & - & - & + & - & source of carbonate & natural \\
\hline Chaetomorpha crassa & - & + & - & - & biogas & cultivated \\
\hline Ulva lactuca & + & + & + & + & Ethanol, methane & cultivated \\
\hline Ulva fasciata & + & + & + & + & Ethanol, methane, algicidal compound & cultivated \\
\hline Bornetella nitida & - & - & - & - & & natural \\
\hline
\end{tabular}

Source: Dawes (1981), Rajathi et al. (2003), Kadi (2004), Hwang et al. (2007), Alamsjah et al. (2007), Kumar et al. (2009), Kantachumpoo \& Chirapart (2010), Leliaert et al. (2011), Sangeetha et al. (2011), Vijayabaskar \& Shiyamala (2012), Kalsum (2012), Kraan (2013), Redmond et al. (2014a), Redmond et al. (2014b) 
Seaweed is a major source of income for thousands of small Indonesian farmers, as well as collectors, traders, exporters, and producers. Some species have been tried to cultivate using either vegetative or generative cultivation methods, with natural and artificial seeding technique. Over the last couple of decades different seaweeds cultivation systems have been developed. The cultivation technique developed and improved starting from intertidal fixed and floating bottom farms for Eucheuma, Kappaphycus and Gracilaria in Philippines, Vietnam, and Thailand; then to elaborate floating net structures for Porphyra; and long-line systems for kelp in China, Korea and Japan (Kraan, 2013). Some species were successfully cultivated, and others still need technical improvement. Gelidium has been cultivated in Korea, China, Spain, Portugal, South Africa, and Israel (Friedlander, 2007). In Indonesia, only three main taxa which have been commonly developed with artificial methods, that are Kappaphycus, Eucheuma, and Gracilaria; some other potential species still in research and development level process. In Asia, native species have been isolated from wild populations; strains have been selected for desirable traits and are maintained as seed cultures (Redmond et al., 2014a; Redmond et al., 2014b). Several seaweeds species have been successfully incorporated into a number of demonstration and pilot scale IMTA (integrated multi-trophic aquaculture) and nutrient bio-extraction systems (Barrington et al., 2009; Troell, 2009; Redmond et al., 2014a; Radiarta et al., 2014).

Several important seaweed species from Labuhanbua coastal water which have a high economical value by producing many substances for human food as well as industrial supplies; need to be developed and cultured intensively. Nine Rhodophyta species of five genera found are belonged to economically important seaweed species that have been cultivated, including Kappaphycus, Eucheuma, Gracilaria, Gelidium, and Porphyra; but only one from total eight Phaeophyta species have been cultivated, i.e Sargassum sp. (Table 3). Thirteen Chlorophyta species found at Labuhanbua; only four species have been cultivated including Codium sp., Caulerpa sp., $U$. lactuca, and $U$. fasciata. Other noncultivated species have their specific economic value that come from each substance that can be produced (Table 3). Phaeophyta species including Turbinaria, Dictyota, Padina, Stoechospermum, and Hydroclathrus; and Chlorophyta species including Halimeda and Chaetomorpha might be some species that could be observed and developed as aquaculture species candidates among the species that were found along this study location. Halimeda sp. has good carbohydrate content about $15,89 \%$, and Turbinaria sp. were found with high carbon content about 22,04\% (Tabel 2); Dictyota sp. and Padina sp. consist sulfated polysaccharide; fucoidan; which have function as antimicrobial substance (Kantachumpoo \& Chirapart, 2010). Those species have potencies as human food, livestock feed, nutraceuticals, cosmetics, pulp, textile, biofuel and any other industries; conversely, they were found in lower density at Labuhanbua coastal waters (Table 1 and 3). Seaweed aquaculture development should be assisted by technological support. Major efforts towards the introduction of seaweeds into commercial cultivation have to involve genetic improvement through selection, breeding, and possibly genetic engineering (Friedlander, 2007). Commercial scale cultivation of those important seaweed species will contribute to industrial supply needs and prevent decreasing of wild seaweed availability on natural ecosystem. This also can help local people around coastal area to increase their economic level. In addition, the development of seaweed aquaculture through commodities diversifying will enhance Indonesian fisheries production and encourage national production target attainment to double of 2014 production volume, during next five years in 2019.

\section{Conclusions}

Seven important seaweed species including Turbinaria, Dictyota, Padina, Stoechospermum, Hydroclathrus, Halimeda, and Chaetomorpha, were found at Labuhanbua coastal waters which are not yet cultivated; which could be observed and developed as aquaculture species candidates. These species contain several high value substances that can be utilized for any purpose i.e. human food, livestock feed, nutraceuticals, cosmetics, pulp, textile, biofuel and any other industries. Commercial scale cultivation of these important seaweed species will contribute to industrial supply needs and prevent decreasing of wild seaweed availability on natural ecosystem; also can help local people around coastal area to increase their economic level. Seaweed aquaculture commodities diversification are expected to support national seaweed production target attainment in 2019 about 22 million tons. 


\section{Acknowledgements}

We acknowledge the local marine and fisheries authority in Sumbawa Regency, West Nusa Tenggara Province. We greatly appreciate the helping of field data collection by Dr. Joni Haryadi and Dr. Ofri Johan. This project was financed by the Government of Indonesia through DIPA 2014.

\section{References}

Alamsjah, M.A., Hirao, S., Ishibashi, F., Oda, T., Fujita, Y., 2007, Algicidal activity of polyunsaturated fatty acids derived from Ulva fasciata and U. pertusa (Ulvaceae, Chlorophyta) on Phytoplankton. Journal of Applied Phycology 20 (5): 263-270.

Barrington, K., Chopin, T., Robinson, S., 2009, Integrated multi-trophic aquaculture (IMTA) in marine temperate waters. In Soto D (ed.). Integrated mariculture: a global review. FAO Fisheries and Aquaculture Technical Paper 529: 7-46.

Carlsson, A.S., van Beilen, J.B., Möller, R., Clayton, D., 2007, Micro- and macroalgae: utility for industrial applications. In: Bowles D. (ed) EPOBIO: Realising the Economic Potential of Sustainable Resources - Bioproducts from Non-food Crops. CPL Press, UK, 82p.

Chakraborty, S., Santra, S.C., 2008, Biochemical composition of eight benthic algae collected from Sunderban. Indian Journal of Marine Sciences 37 (3): 329332.

Dawes, C.J.1981. Marine Botany. John Wiley and Sons, Inc., Canada, 628pp.

Dhargalkar, V.K., Kavlekar, D., 2004, Seaweeds: A field manual. National Institute of Oceanography, New Delhi, $36 \mathrm{pp}$.

Diaz-Pulido, G., McCook, L., 2008, Environmental Status: Macroalgae (Seaweeds). Great Barrier Reef Marine Park Authority, Townsville, 44pp.

[DGA-MMAF] Directorate General of Aquaculture - Ministry of Marine Affair and Fisheries, 2015, Indonesian Aquaculture Statistics 2014. DGA, Ministry of Marine Affair and Fisheries Republic of Indonesia, Jakarta, 159pp.

Erlania, Radiarta, I.N., 2014a, The use of seaweeds aquaculture for carbon sequestration: a strategy for climate change mitigation. Journal of Geodesy and Geomatics Engineering 2: 109-115.

Erlania, Radiarta, I.N., 2014b, Management of sustainable seaweed (Kappaphycus alvarezii) aquaculture in the context of climate change mitigation. Indonesian Aquaculture Journal, 9 (1): 65-72.

[FAO] Food and Agricultural Organization of the United Nations, 2012, The State of the World Fisheries and Aquaculture 2012. FAO Fisheries Department, Rome, 209pp.

[FAO] Food and Agricultural Organization of the United Nations, 2014, The State of the World Fisheries and Aquaculture 2014: Opportunities and challenges. FAO Fisheries Department, Rome, 223pp.

Friedlander, M., 2007, Advances in cultivation of Gelidiales. Journal of Applied Phycology 20 (5): 1-6.

Hwang, E.K., Baek, J.M., Park, C.S., 2007, Cultivation of the green alga, Codium fragile (Suringar) Hariot, by artiificial seed production in Korea. Journal of Applied Phycology, 20 (5): 19-25.

Kadi, A., 2004, Potensi rumput laut di beberapa perairan pantai Indonesia. Oseana XXIX (4): 25-36.

Kaladharan, P., Veena, S., Vivekanandan, E., 2009, Carbon sequestration by a few marine algae: Observation and projection. Journal of the Marine Biological Association of India 51 (1): 107-110.

Kalsum, S.J., 2012, Jenis jenis rumput laut. Seaplant.Net. 100pp.

Kantachumpoo, A, Chirapart, A., 2010, Components and antimicrobial activity of polysaccharides extracted from Thai brown seaweeds. Kasetsart Journal (Natural Science) $44:$ 220-233.

Kraan, S., 2013, Mass-cultivation of carbohydrate rich macroalgae, a possible solution for sustainable biofuel production. Mitigation and Adaptation Strategies for Global Change Journal, 18: 27-46.

Kumar, S., Kumar, Y., Khan, M.S.Y., Anbu, J., De Clercq, E., 2009, Antihistaminic, anticholinergic, and antiviral activities of fucosterol from Turbinaria conoides (J.Agardh) Kutzing. Pharmacology Online 1: 1104-1112. 
Leliaert, F., D'hondt, S., Tyberghein, L., Verbruggen, H., De Clerck, O., 2011, A typical development of Chaetomorpha antennina in culture (Cladophorales, Chlorophyta). Phycological Research 59: 91-9.7

Manivannan, K., Thirumaran, G., Devi, G.K., Hemalatha, A., Anantharaman, P., 2008, Biochemical composition of seaweeds from Mandapam Coastal Regions Along Southeast Coast of India. AmericanEurasian Journal of Botany 1 (2): 32-37.

McHugh, D.J., 2003, A Guide to Seaweed Industry. FAO Fisheries Technical Paper 441: 105pp.

Naguit, M.R.A., Tisera, W.L., 2009, Pigment analysis on Eucheuma denticulatum (Collins \& Hervey) and Kappaphycus alvarezii (Doty) cultivars cultured at different depths. Threshold 4: 29-37.

Neto, A.I., 2000, Ecology and dynamics of two intertidal algal communities on the littoral of the island of São Miguel (Azores). Hydrobiologia 432: 135-147.

Park, C.S., K.Y. Park, J.M. Baek, and E.K. Hwang. 2007. The occurence of pinhole disease in relation to developmental stage in cultivated Undaria pinnatifida (Harvey) Suringar (Phaeophyta) in Korea. Journal of Applied Phycology 20 (5): 35-40.

Pise, N.M., and A.B. Sabale. 2010. Biochemical Composition of Seaweeds along Central West Coast of India. Pharmacognosy Journal 2 (7): 148-150.

Radiarta, I.N., Erlania, Sugama, K., 2014, Budidaya rumput laut, Kappaphycus alvarezii, secara terintegrasi dengan ikan kerapu di Teluk Gerupuk Kabupaten Lombok Tengah, Nusa Tenggara Barat. Jurnal Riset Akuakultur 9 (1): 125-134.

Rajathi, F.A.A., Parthiban, C., Kumar, V.G., Anantharaman, P., 2003, Biosynthesis of antibacterial gold nanoparticles using brown alga, Stoechospermum marginatum (kützing). Spectrochimica Acta Part A: Molecular and Biomolecular Spectroscopy 99: 166-173.
Redmond, S., Green, L., Yarish, C., Kim, J., Neefus, C., 2014a, New England Seaweed Culture Handbook-Nursery Systems. Connecticut University - Sea Grant CTSG-14-01. 92pp.

Redmond, S., Kim, J.K., Yarish, C., Pietrak, M., Bricknell, I., 2014b, Culture of Sargassum in Korea: techniques and potential for culture in the U.S. Orono. ME: Maine Sea Grant College Program, Sea Grant and NOAA-MOF Joint Project. $14 p p$.

Sahayaraj, K., Rajesh, A., Asha, A., Rathi, J.M., Raja, P., 2014, Distribution and diversity assessment of the marine macroalgae at four southern disctricts of Tamil Nadu, India. Indian Journal of Geo-Marine Sciences 43 (4): 607-617.

Sangeetha, P., S. Babu, and R. Rengasamy. 2011. Potential of green alga Chaetomorpha litorea (Harvey) for biogas production. International Journal of Current Science 1: 24-29.

Shibu, A., Dhanam, S., 2013, Investigation of in vitro antibacterial evaluation of some marine algae collected from Gulf of Mannar, Tamil Nadu. International Journal of Recent Scientific Research 4 (4): 376- 380.

Thirumaran, G., Anantharaman, P., 2009, Daily growth rate of field farming seaweed Kappaphycus alvarezii (Doty) Doty ex P. Silva in Vellar Estuary. World Journal of Fish and Marine Sciences 1(3): 144-153.

Troell, M., 2009, Integrated marine and brackishwater aquaculture in tropical regions: research, implementation and prospects. In: Soto D (Ed.), Integrated mariculture: a global review. FAO Fisheries and Aquaculture Technical Paper 529: 47-131.

Tyler, R.M., 2010, Seaweed Distribution and Abundance in the Inland Bays. FY09 Research and Demonstration Project, Delaware Department of Natural Resources and Environmental Control, $18 p p$.

Varela-Álvarez, E., 2007, Seasonal growth and phenotypic variation in Porphyra linearis (Rhodophyta) populations on the west coast of Ireland. Journal of Phycology 43: $90-100$. 
Vásquez, J.A., 2007, Production, use and fate of Chilean brown seaweeds: re-source for a sustainable fishery. Journal of Applied Phycology 20 (5): 7-17.

Vijayabaskar, P., Shiyamala, V., 2012, Antioxidant properties of seaweed polyphenol from Turbinaria ornata (Turner) J. Agardh, 1848. Asian Pacific Journal of Tropical Biomedicine 2 (1): S90-S98.

Seo, Y-B., Lee, Y-W., Lee, C-H., You, H-C., 2010, Red algae and their use in papermaking. Bioresource Technology 101: 2549-2553. 